\title{
ASSET UTILIZATION OPTIMIZATION, LOCAL GOVERNMENT SUPPORT, ASSET MANAGEMENT PROFESSIONALISM TOWARDS INCREASING VILLAGE ORIGINAL INCOME
}

\author{
Erna Hendrawati* \\ Universitas Wiijaya Kusuma Surabaya \\ hendrawati@uwks.ac.id
}

\begin{abstract}
This study aims to examine and analyze the effect of optimizing asset utilization, local government support, asset management professionalism on increasing Village Original Income (PA Desa). The research population is village officials in Menganti District, Gresik Regency, East Java. The questionnaire that can be obtained is 160 respondents. The data analysis techniques are validity test, reliability test, classical assumption test and multiple regression test. The results of the optimization of asset utilization and asset management professionalism affect village original income, while government support does not affect village original income. This can happen because village officials are aware that by optimizing asset utilization and managing assets professionally, they can increase the village's original income even though there is and no support from the government.
\end{abstract}

Keywords: Optimizing the use of village assets, Neighborhood Government support, The professionalism of Village Asset Management, Village Original Income

*Corresponding author:

Email: hendrawati@uwks.ac.id

DOI: https://doi.org/10.33369/j.akuntansi.11.2.163-174

\section{INTRODUCTION}

Law No. 6 of 2014 concerning Villages, in light of the law, the town head as the holder of the greatest expert in the town has full power to manage and foster his town. Designating power to the town government, the focal government gives assets to every town that is considered equipped for overseeing itself (Atmadja and Saputra, 2017). The arrangement of town reserves, one of which has the point of being a boost and inspiration so towns can advance and be autonomous in fostering the town economy. This can be accomplished if the town can use its resources and resources for acquire extra town pay separated from town reserves, town store allotments and help from locale, areas and the focal government.

Usage of town resources should be possible by using town resources that are not utilized as per the principle assignments and elements of the organization as rental, acquiring, use collaboration and building handover/work over without changing the situation with town resources (Yabbar, 2015). Ideal use of town resources will set out work open doors, increment town local area pay, diminish destitution, increment town pay and lessen differences among inhabitants and between towns. Advancement of resource usage is the connection between administration convenience and benefit reward. Resource streamlining is improving the use of a resource which can create more advantages or additionally acquire pay. The aftereffects of exploration by Natalia (2017), Marvilianti (2017) got that resource improvement positively affects expanding town unique pay.

As well as being utilized, town resources should be overseen. The executives of town resources is a progression of exercises beginning from arranging, obtainment, use, use, security, upkeep, end, move, organization, detailing, appraisal, direction, management and control of town resources (Permendagri No. 1 of 2016 concerning Village Asset Management). Resource the board demonstrable skill is more focused on the capacity of the mechanical assembly in 
giving great, reasonable, and comprehensive administrations and not simply the match of aptitude with the spot of task. With the goal that the device is needed to have the capacity and aptitude to comprehend and interpret the yearnings and requirements of the local area into administration exercises and projects (Riyanto, 2014). For this situation, the polished skill of the town device can completely characterize town resource the board projects to make it simpler as far as the executives and oversight. The board of Village Original Income (PADes) is completed dependent on the standards of being straightforward, responsible, participatory, just as organized and restrained, assessed from arranging, planning, organization, announcing, responsibility to oversight (Astuti, 2015). As per Sedarmayanti (2013) polished methodology is a column that will put the organization as a successful machine for the public authority and as a boundary of the contraption's abilities in functioning admirably. The proportion of polished skill is capability, proficiency and adequacy just as obligation. The presence of resource the board polished skill is relied upon to give extra town pay. As the aftereffects of examination directed by Natalia (2017), Marvilianti (2017), improvement of town resource the board has a critical positive relationship to town unique pay.

Town government support identified with town resources is tutoring, training, observing town resources, controlling town resources (Yabbar, 2015). The advancement of town claimed resources is a business or movement through the arrangement of rules, direction, preparing and oversight to guarantee the smooth execution of productive and viable administration of town possessed resources. The arrangement of rules is significant in the execution of town resource the board. The rule is a reference for acceptable behavior from the execution in overseeing town resources. Direction in instructing is fundamental on the grounds that composed rules can in any case prompt various discernments, for that direction is required. Direction is normally done through socialization or workshops for town authorities who oversee town resources actually, this should be possible by leading preparing. Assuming in the execution there are snags, management is expected to take care of issues in the field. Resource management is a business or movement to discover and survey the established truths in regards to the execution of assignments and additionally exercises, regardless of whether did as per the laws and guidelines. Oversight incorporates organized execution of the utilization, usage and move of Village resources as per pertinent guidelines. Control is completed to guarantee and direct that the work did goes as indicated by the foreordained arrangement. The motivation behind carrying out town claimed resource control is to give sufficient certainty to the adequacy and proficiency of accomplishing the goals of town administration, particularly the executives of property resources, security of town possessed resources and consistence with legal guidelines. The aftereffects of the examination that help the neighborhood government impact the town's unique pay.

This research was conducted in Menganti sub-district, Gresik district, East Java, where from 2016 to 2020 the village's original income increased, although there was a decrease in 2017. The original income of the sub-district village was as follows:

Table 1. Original income of Menganti sub-district village

\begin{tabular}{ccc}
\hline Year & $\begin{array}{c}\text { Total Village Original } \\
\text { Income (Rp) }\end{array}$ & $\begin{array}{c}\text { Improvement compared } \\
\text { to 2016 }(\%)\end{array}$ \\
\hline 2016 & 1.743 .193 .000 & $24,34 \%$ \\
\hline 2017 & 1.722 .774 .000 & $-1,17 \%$ \\
\hline 2018 & 1.797 .123 .000 & $3,094 \%$ \\
\hline 2019 & 1.898 .171 .000 & $8,89 \%$ \\
\hline 2020 & 1.975 .500 .000 & $13,33 \%$ \\
\hline \multicolumn{2}{l}{ Source : primasy data obtained }
\end{tabular}


In view of the foundation and conditions over, the scientist needs to test whether the advancement of resource use, government support, polished methodology in resource the board affects expanding town unique pay. With the expectation of giving data on which factors the town can do to improve its unique assessment.

Natalia, et al., (2017) expressed that advancing the utilization of resources has a huge constructive outcome on expanding town unique pay, this implies that resources in the town should be utilized ideally with a direction to build town unique pay so the town is progressively ready to lead towards an autonomous town. Widayanti (2010) states that the streamlining of the utilization of provincial resources influences the stock and ID of resources. This implies that the enhancement of resource use can possibly increment local pay via completing a stock and distinguishing proof utilizing a decent framework. The assertion additionally expresses that to build the town's unique pay, proficient administration of town resources is required and is trailed by enhancing the utilization of resources claimed by the town. This is considered prepared to do altogether expanding the town's unique pay. This implies that proficient resource the board is required in expanding town pay, just as using useful town potential that will actually want to build town pay. The administration (the executives) of territorial resources is one of the determinants of sound business execution. Resource the board, which contains the improvement of resource use, is a powerful methods for improving execution so that work straightforwardness in resource the executives is ensured without the requirement for worries about frail management and control (Siregar, 2004). In view of the consequences of past research over, the speculation can be defined in this examination, specifically:

$\mathrm{H} 1$ : Optimizing the use of village assets affects the village's original income

Saputra and Julianto (2016) expressed that nearby government support in overseeing town reserves is demonstrated through management as the Draft APBDes prior to being dictated by the Town Head should be directed and assessed. For management with regards to reviewing, up to this point there is no overseeing guideline. Nonetheless, the current show concurs that reviews ought to be done by locale/city inspectorates. Atmadja and Saputra (2017) express that the collaboration or backing of neighborhood governments for town governments is imperative to help town reserve the executives exercises. The aftereffects of his examination express that neighborhood government support positively affects the administration of town reserves, which can be deciphered that the positive impact being referred to is that nearby government support, straightforwardly or by implication, is as yet required by the Town Government in each movement in the town and one of them is in deciding town potential and advancement. BUMDesa. In light of the aftereffects of past research over, the speculation can be planned in this investigation, in particular:

$\mathrm{H}_{2}$ : Neighborhood government support influences the town's own pay

Dewi, et al., (2017), in their exploration results express that the polished skill of town resource the executives has an incorporated relationship, implying that proficient resource the board is surely important to give local area trust in town government and local area monetary turn of events and improvement programs. through proficient administration of BUMDesa. The aftereffects of exploration from Dewi, et al.,(2018) express that the polished methodology of resource the board impacts the town's unique pay. This shows that proficient resource the board is required by the town. As far as overseeing town potential and planning just as monetary administration in town specialty units or BUMDesa. Resource the executives polished skill requires proficient assets just as a decent framework consideration and full help from all gatherings. In view of the consequences of past research, the accompanying examination speculation can be detailed: 
$\mathrm{H}_{3}$ : Professionalism in the management of village assets affects the village's original income

\section{RESEARCH METHODS}

The number of inhabitants in this exploration is the towns that get Town Assets in the Menganti Region of Gresik Rule. The towns remembered for the Menganti sub-region comprise of 22 towns to be specific Pranti, Bringkang, Mojotengah, Menganti, Hulaan, Sidowungu, Setro, Laban, Pengalangan, Randupadang, Drancang, Palemwatu, Sidojangkung, Domas, Gadingwatu, Beton, Putat Lor, Boteng, Boboh, Gempolkurung, Kepatihan, Hendrosari. Respondents of this investigation were the Town Head, Town Secretary, Head of Administration, Government assistance, Government, Head of Account, General Issues and Arranging, adding up to 175 respondents.

The information utilized in this exploration is quantitative information, and the essential information source is gotten and gathered straightforwardly from the examination area, in particular government authorities in the sub-region changing through a survey. The survey was disseminated to the WhatsApp bunch in every town utilizing the google structure. The information assortment strategy utilizes a shut poll, in particular a survey that has given answer alternatives to be chosen by the object of examination. The poll starts from past investigations and the creation of surveys with changes through hypothesis and guideline, and acclimated to the requirements of the exploration article and markers whose legitimacy and dependability have been tried. Specialists expect respondents who will answer the poll given are individuals who think about the extent of town resource the board as a feature of the town's unique pay.

\section{Optimizing the use of village assets $\left(\mathrm{X}_{1}\right)$}

Streamlining the usage of town resources is the use of town resources that are not utilized as per the principle undertakings and elements of the organization as rental, getting, use collaboration and building handover/work over without changing the situation with town resources (Yabbar, 2015). Estimation of the streamlining of the usage of town resources utilizing pointers in the exploration of Dewi, et al (2017) which comprises of correspondence, assets, and manner. So, the operational improvement of resource usage alludes to these three components with different adjustments of survey questions that are adjusted to the extent of the examination. The quantity of poll explanations added up to 15 proclamations contained in the exploration survey with the aftereffects of reactions utilizing a Likert scale 1-5 going from "exceptionally low" at the lower furthest reaches of the scale (1) and "extremely high" at the maximum furthest reaches of the scale (5).

\section{Neighborhood Government support (X2)}

Neighborhood government support is estimated by creating research pointers as indicated by Yabbar and Hamzah (2015) specifically tutoring, instructing, checking town claimed resources, controlling town possessed resources. The help, direction and oversight completed by the local government is through cultivating the planning of provincial guidelines concerning towns, instructing in the designation of town reserves, expanding the limit of town authorities, town government the board, encouraging in speeding up town advancement just as leading specialized direction and management of the assurance of the RAPBD ( Draft Territorial Income and Use Financial plan) in town financing. Likewise, help, direction and management are additionally done by Regime/Metropolitan Governments as far as drafting Town Guidelines, drafting advancement plans, working with the execution of town government, deciding the financing of adjusting store distributions for towns, just as leading direction and oversight in the system of good town administration. great (Yabbar and Hamzah, 2015). These pointers were formed into 10 explanation things contained in the examination poll 
with the aftereffects of reactions utilizing a Likert scale 1-5 going from "low" at the lower furthest reaches of the scale (1) and "high" at the maximum furthest reaches of the scale (5).

\section{The professionalism of Village Asset Management (X3)}

Polished methodology is the capacity of the contraption in giving great, reasonable, and comprehensive administrations and not simply a match of mastery with the spot of task (Riyanto, 2014). Resource the board polished methodology is estimated by capacity, quality, offices and framework, number of (HR), data innovation and dependability Dewi et al., (2018). Polished methodology was estimated utilizing an examination instrument from Dewi et al., (2018) which was completed dependent on the resource the executives demonstrable skill cycle and acclimated to Unofficial laws. Number 43 of 2014 concerning executing guidelines of Law Number 6 of 2014 article 108, to be specific arranging, acquisition, use, use, security, upkeep, disposal, move, organization, revealing, evaluation, direction, and oversight and control. The quantity of poll proclamations added up to 10 explanations contained in the examination survey with the aftereffects of reactions utilizing a Likert scale 1-5 going from "low" at the lower furthest reaches of the scale (1) and "high" at the maximum furthest reaches of the scale (5).

\section{Village Original Income ( Y )}

The indicator of the village original income variable is derived from the concept of village development which requires costs and can be obtained from several sources, one of which is village original income. There are several sources of village original income that can be managed as a village financial source, namely village business results, village wealth management results, results of self-help and participation, mutual cooperation results and other legitimate village original income (Dewi, et al (2017). The source of village original income is also set as an indicator of village original income and is integrated with Law Number 6 of 2014 concerning Villages which contains village original income posts, namely village business results, village wealth management results, results of self-help and participation, results of mutual assistance. cooperation and other legitimate village original income The number of questionnaire statements is 6 statements contained in the research questionnaire with the results of responses using a Likert scale 1-5 ranging from "very low" on the lower limit of the scale (1) and "very high" at the upper limit of the scale (5).

\section{Population, Sample and Data Analysis Techniques}

The organization of the poll answers will be tried for legitimacy and unwavering quality. Legitimacy test to quantify how genuine a test or instrument is. The legitimacy of the information in this examination was tried genuinely by ascertaining the connection between's each question and the complete score utilizing the Item Second Pearson Relationship technique. The information is supposed to be substantial if the worth of r-tally which is the worth of Revised Thing Absolute Correlation > from the r-table with a meaning of 0.05 (5\%) (Ghozali, 2011). Unwavering quality shows the consistency of estimating instruments in estimating similar manifestations on different events. The exploration survey is supposed to be solid or dependable if an individual's answers are reliable with the inquiries (Ghozali, 2011). Unwavering quality estimation is finished by estimating the connection between's answers. Assuming the Cronbach Alpha worth is $>0.60$, a variable is supposed to be solid.

This exploration is delegated a quantitative examination so that testing is expected to test the relationship of the free factor to the reliant variable where in this investigation the point is to see the impact of the autonomous variable on the reliant variable, at that point a relapse test is done so the information utilized in this investigation has finished the traditional supposition assessment which incorporates the ordinariness test, multicollinearity, heteroscedasticity and autocoleration in this way can be proceeded with the relapse test. To 
have the option to answer the detailing of the issues in this examination, the tests completed were the assurance test $\left(\right.$ Changed $\mathrm{R}^{2}$ ) and the $\mathrm{F}$ test.

\section{RESULTS AND DISCUSSION \\ Examination Article Outline}

The object of this examination is the towns that are remembered for the Menganti subregion, Gresik Regime. Menganti sub-area limit: north of Cerme sub-locale, east of Lakarsantri sub-region, south of Driyorejo sub-region, west of Kedamean sub-region. There are 22 towns remembered for the sub-region, in particular Pranti, Bringkang, Mojotengah, Menganti, Hulaan, Sidowungu, Setro, Laban, Pengalangan, Randupadang, Drancang, Palemwatu, Sidojangkung, Domas, Gadingwatu, Beton, Putatlor, Boteng, Boboh, Gempolkurung towns, Kepatihan, Hendrosari. 21 towns are classified as autonomous towns and one town is sorted as free towns, to be specific Boboh town (BPS, 2020). The town government is going by the town head/lurah helped by the town secretary/lurah secretary. In executing the public authority, it is helped by 3 ssksi heads (head of administration, government assistance, government area), 3 heads of undertakings (account, general and arranging). The pay of towns in the menganti subarea comes from: town unique pay, town reserves, shared expenses and requires, some portion of the equilibrium store (ADD), government monetary help from the locale and 1 town in 2019 to get monetary help from the commonplace government, to be specific the town of Menganti, adding up to $36,375.000$ (BPS, 2020).

\section{Respondent Personality Depiction}

Respondents of this examination were town authorities associated with town monetary administration including the Town Head, Town Secretary, Head of Administration, Government assistance, Government, Head of Monetary Undertakings, General Issues and Arranging, adding up to 175 respondents. Of the 22 towns, there is one town that doesn't have a town secretary, in particular Bringkang town. From the surveys dispersed by means of Whatsapp bunch with google structure, 160 respondents $(91.4 \%)$ and 15 respondents $(8.6 \%)$ didn't round out the poll.

Table 2. Questionnaire Distribution Tabulation

\begin{tabular}{llcc}
\hline No & \multicolumn{1}{c}{ Information } & Number of Respondents & Percent \\
\hline 1 & Number of questionnaires were distributed & 175 & $100 \%$ \\
\hline 2 & Questionnaires were not filled & 15 & $8,6 \%$ \\
\hline 3 & Questionnaires were filled & 160 & $91,4 \%$ \\
\hline \multicolumn{2}{l}{ Source: Resoundents' Answers }
\end{tabular}

Of the 160 respondents complex sex female 45 respondents, or as much as $28.1 \%$ and 115 respondents $(71.9 \%)$ men. So as can be presumed that the gadget towns in subdistrict Menganti many are complex sex male suit table beneath is:

Table 3. Characteristics of respondents by gender

\begin{tabular}{ccc}
\hline Respondents & Frequency (people) & Percent \\
\hline Women & 45 & $28,1 \%$ \\
\hline Man & 115 & $71,9 \%$ \\
\hline Total & 160 & $100 \%$ \\
\hline
\end{tabular}

Source: Resoundents' Answers frequency

A sum of 115 respondents had ages $40-59$ years or as much as $71.9 \%$ of the whole respondents. $23.7 \%$ were matured $25-39$ years and $4.4 \%$ were $>60$ years of age. This is as indicated by the table as follows: 
Table 4. Characteristics of Respondents by age

\begin{tabular}{ccc}
\hline Age Range & Frequency (people) & Percent \\
\hline $25-39$ & 38 & $23,7 \%$ \\
\hline $40-59$ & 115 & $71.9 \%$ \\
\hline$>60$ & 7 & $4,4 \%$ \\
\hline Total & 160 & $100 \%$ \\
\hline
\end{tabular}

Source : Resoundents' Answers frequency

\section{Validity Test Results}

Determination of the validity test using the Pearson product moment correlation method. Validity test can be known if the significance $<0.05$ and correlation $>0.4$ then the data is said to be valid.

\begin{tabular}{cccc} 
Table 5. Variable Validity of Asset Utilization Optimization Variables (X1) \\
\hline $\begin{array}{c}\text { Statement } \\
\text { items }\end{array}$ & $\begin{array}{c}\text { Correlation } \\
\text { coefficient }\end{array}$ & Significance & Information \\
\hline 1 & 0,690 & 0,000 & Valid \\
\hline 2 & 0,648 & 0,000 & Valid \\
\hline 3 & 0,598 & 0,000 & Valid \\
\hline 4 & 0,621 & 0,000 & Valid \\
\hline 5 & 0,543 & 0,000 & Valid \\
\hline 6 & 0,620 & 0,000 & Valid \\
\hline 7 & 0,570 & 0,000 & Valid \\
\hline 8 & 0,560 & 0,000 & Valid \\
\hline 9 & 0,625 & 0,000 & Valid \\
\hline 10 & 0,540 & 0,000 & Valid \\
\hline 11 & 0,590 & 0,000 & Valid \\
\hline 12 & 0,456 & 0,000 & Valid \\
\hline 13 & 0,636 & 0,000 & Valid \\
\hline 14 & 0,578 & 0,000 & \\
\hline 15 & 0,499 & 0,000 & \\
\hline
\end{tabular}

Source : SPSS data processing result

The worth of the connection coefficient of the Resource Usage Advancement variable is more noteworthy than 0.4 and the importance is under 0.05 , it implies that the general assertion thing is legitimate.

Table 6. Variable Validity of Local Government Support Variables (X2)

\begin{tabular}{cccc}
\hline Statement items & Correlation coefficient & Significance & Information \\
\hline 1 & 0,728 & 0,000 & Valid \\
\hline 2 & 0,541 & 0,000 & Valid \\
\hline 3 & 0,490 & 0,000 & Valid \\
\hline 4 & 0,530 & 0,000 & Valid \\
\hline 5 & 0,540 & 0,000 & Valid \\
\hline 6 & 0,697 & 0,000 & Valid \\
\hline 7 & 0,620 & 0,000 & Valid \\
\hline 8 & 0,610 & 0,000 & Valid \\
\hline 9 & 0,576 & 0,000 & Valid \\
\hline 10 & 0,633 & 0,000 & Valid \\
\hline
\end{tabular}

Source : SPSS data processing result

The worth of the relationship coefficient of government support is more noteworthy than 0.4 and the importance is under 0.05, it implies that the general assertion thing is legitimate. 
ASSET UTILIZATION OPTIMIZATION, LOCAL GOVERNMENT SUPPORT, ASSET MANAGEMENT PROFESSIONALISM TOWARDS INCREASING VILLAGE ORIGINAL INCOME

Erna Hendrawati

Table 7. Variable Validity of the Asset Management Professionalism (X3)

\begin{tabular}{cccc}
\hline Statement items & Correlation coefficient & Significance & Information \\
\hline 1 & 0,745 & 0,000 & Valid \\
\hline 2 & 0,723 & 0,000 & Valid \\
\hline 3 & 0,758 & 0,000 & Valid \\
\hline 4 & 0,741 & 0,000 & Valid \\
\hline 5 & 0,695 & 0,000 & Valid \\
\hline 6 & 0,540 & 0,000 & Valid \\
\hline 7 & 0,675 & 0,000 & Valid \\
\hline 8 & 0,660 & 0,000 & Valid \\
\hline 9 & 0,520 & 0,000 & Valid \\
\hline 10 & 0,576 & 0,000 & Valid \\
\hline
\end{tabular}

Source : SPSS data processing result

The value of the correlation coefficient of government support is greater than 0.4 and the significance is less than 0.05 , it means that the overall statement item is valid.

Table 8. Variable Validity of Increasing Village Original Income (Y)

\begin{tabular}{cccc}
\hline Statement items & Correlation coefficient & Significance & Information \\
\hline 1 & 0,554 & 0,000 & Valid \\
\hline 2 & 0,729 & 0,000 & Valid \\
\hline 3 & 0,755 & 0,000 & Valid \\
\hline 4 & 0,778 & 0,000 & Valid \\
\hline 5 & 0,725 & 0,000 & Valid \\
\hline 6 & 0,665 & 0,000 & Valid \\
\hline
\end{tabular}

Source : SPSS data processing result

The worth of the relationship coefficient of town unique pay is more noteworthy than 0.4 and the importance is under 0.05 , it implies that the general assertion thing is substantial.

\section{Reliability Test Results}

Dependability test was directed to show how solid the instrument utilized was a lot utilized as an information assortment apparatus. The consequences of the dependability test can be checked whether the Cronbach Alpha worth is 0.60 then it is proclaimed solid (dependable) and assuming the Cronbach Alpha worth is 0.40 , it is announced very dependable.

Table 9. Reliability Test Results

\begin{tabular}{llcc}
\hline No. & \multicolumn{1}{c}{ Variable } & Cronbach 's Alpha & Information \\
\hline 1 & Optimizing the use of village assets (X1) & 0,600 & Reliabel \\
\hline 2 & Neighborhood Government support (X2) & 0,608 & Reliabel \\
\hline 3 & The professionalism of Village Asset Management (X3) & 0,776 & Reliabel \\
\hline 4 & Village Original Income (Y) & 0,841 & Reliabel \\
\hline \multicolumn{2}{l}{ Source : SPSS data processing result } & &
\end{tabular}

Based on the results of the reliability test of the four variables, it shows Cronbach's alpha $>0.6$, meaning that the questionnaire statement items to measure $\mathrm{X} 1, \mathrm{X} 2, \mathrm{X} 3$ and $\mathrm{Y}$ are consistent as a measuring tool. In view of the information got and had gotten away from test the suppositions of traditional then can do the test regr e si numerous as that seen table beneath this:

Table 10. The results of multiple linear regression tests

\begin{tabular}{lcccc}
\hline Variable & Coefficient & Significance & Alpha & Decision \\
\hline Optimizing the use of village assets (X1) & 0,563 & 0,004 & 0,05 & $\mathrm{H}_{1}$ welcome \\
\hline Neighborhood Government support (X2) & 0,331 & 0,525 & 0,05 & H2 rejected \\
\hline
\end{tabular}




\begin{tabular}{lcccc}
\hline \multicolumn{1}{c}{ Variable } & Coefficient & Significance & Alpha & Decision \\
\hline $\begin{array}{l}\text { The professionalism of Village Asset } \\
\text { Management (X3) }\end{array}$ & 0,364 & 0,020 & 0,05 & H3 welcome \\
\hline Constant : 0.695 & & & & \\
Dependent variable : Village Original Income & & & \\
Adjusted R Square : 0,443 & & & \\
F statistics : 11.664 & & & \\
Significance : 0,000 & & &
\end{tabular}

Based on the table above, the regression equation is as follows:

$\mathrm{Y}=0,695+0,563 \mathrm{X}_{1}+0,331 \mathrm{X}_{2}+0,364 \mathrm{X}_{3}+e$

The consequence of the coefficient of assurance test shows that the worth of R Square $\left(\mathrm{R}^{2}\right)$ of 0.443 demonstrates that the variable of resource use enhancement, nearby government support, proficient resource the executives can clarify changes in the increment in town unique pay by $44.3 \%$ while the leftover $55.7 \%$ is the impact of autonomous factors in past the relapse model condition in this investigation. In light of the consequences of the t-test to discover how the connection between the free factors, to be specific advancement of resource use, neighborhood government support, resource the board polished methodology towards expanding unique pay shows that the improvement of resource usage has a coefficient of 0.563 with an importance level of 0.004 , the coefficient worth of nearby government support is 0.331 with a sinification level of 0.525 , while the coefficient of resource the board polished methodology is 0.364 with an importance level of 0.020 .

\section{Discussion}

\section{The Effect of Optimizing Asset Utilization on Increasing Village Original Income}

The main theory expresses that improving the utilization of resources affects expanding the town's unique pay. This shows that the usage of town resources possessed by the towns in the Menganti sub-locale can influence the increment in town unique pay. The impact can be seen from the relapse results, the relapse coefficient for enhancing resource usage is positive, implying that the higher the enhancement completed will influence the increment in town unique pay or the other way around. Streamlining the utilization of town resources should be possible by using resources claimed by the town by leasing resources having a place with the town to different gatherings, for example, land or rice fields, structures. Town authorities have the insight that on the off chance that they utilize the resources claimed by the town ideally, it will build the town's unique pay. Usage of resources can be completed by considering the standards of town resource the board like the utilitarian guideline, specifically dynamic and critical thinking in the administration of town resources did by the town head and town authorities as indicated by their individual capacities, specialists and obligations, the rule of lawful sureness, in particular the administration of town resources having a place with the town. should be done dependent on law or legal guidelines, the rule of straightforwardness, to be specific the administration of town possessed resources should be straightforward to the privileges of the town local area in acquiring right data, the rule of proficiency in overseeing town resources is guided so the resources having a place with the town are utilized by the necessary standard impediments In request to help the execution of the primary errands and elements of town government ideally, every action of overseeing town resources should be responsible to the town local area, there is assurance of significant worth in the exactness of the sum and worth of resources in the synopsis. a. advancing the usage and move of resources having a place with the town just as the readiness of a town government monetary record. 
It is as per the aftereffects of the exploration is additionally upheld by Sundari (2014) in (Natalia et al., 2017) to streamline the utilization of resources of land empty which should be possible via lease to the next and is utilized for exercises of reforestation and development of fish freshwater that can add income local to the area. Use of resources via advances made to the resource moves like processing rice, farm haulers to furrow the fields. Usage of resources for awaken to move to add resources were possessed by the town which in the long run could add incomes local town, for example, the production of working to show an authority like weddings and others. Because of the advancement of resource town can add to profit local towns and add the resources are claimed by the town. The consequences of this examination likewise support the exploration (Dewi et al., 2017), which brings about the improvement and polished skill of resource the executives that impacts expanding the town's unique pay.

It is as per the consequences of the exploration is additionally upheld by Sundari (2014) in (Natalia et al., 2017) to advance the utilization of resources of land empty which should be possible via lease to the next and is utilized for exercises of reforestation and development of fish freshwater that can add income local to the area. Usage of resources via credits made to the resource moves like processing rice, farm vehicles to furrow the fields. Use of resources for awaken to move to add resources were claimed by the town which ultimately could add incomes local town, for example, the assembling of working to show an authority like weddings and others. Because of the improvement of resource town can add to profit local towns and add the resources are possessed by the town. The consequences of this examination likewise support the exploration (Dewi et al., 2017), which brings about the streamlining and polished methodology of resource the executives that impacts expanding the town's unique pay.

Permendagri No. 1 of 2016 concerning Village Asset Management, clarifies that the use of town resources can be done as long as they are not utilized straightforwardly to help the execution of Village Government, Utilization of town resources is specified in a Village Regulation, Utilization through Collaborative Utilization, working for handover or working for conveyance to be completed subsequent to acquiring composed consent from the Regent/Mayor, the usage results are town pay and should be gone into the Village Treasury account (Ibnu et al., 2019).

\section{The Effect of Local Government Support on Increasing Village Original Income}

The subsequent speculation is dismissed, this implies that neighborhood government support has no impact on expanding the town's unique pay. This can happen in light of the fact that town authorities in the Menganti sub-area have the insight that the presence and nonappearance of nearby government backing won't influence the town's unique pay. Town authorities understand that the utilization of resources and polished skill in resource the executives will influence the town's unique pay. Neighborhood government backing should be possible by creating and observing town claimed resources. The improvement of town resources is completed by giving rules, direction, preparing and oversight to guarantee the smooth administration of town resources. Rules can be made by giving a reference to acceptable behavior in the administration of town resources. Direction in instructing is important in light of the fact that composed rules alone can in any case prompt various discernments, for that it is important to have direction. Direction is brought out through socialization or workshops to town authorities who oversee town resources in fact through preparing. In the event that there are impediments in the execution, oversight is expected to tackle issues in the field.

The consequences of this investigation repudiate the examination led (Saputra et al., 2019) which expresses that the impact of neighborhood government support on town income. Neighborhood government support for town monetary administration is showed in instructing, both for town heads, authorities and chiefs of BUMDES and ventures in the town. With an end 
goal to build the town's unique pay, the nearby government has explicitly given help with the type of planning the potential in the town through different examinations and dissects from the R\&D so the town government can utilize these outcomes to be executed. The cooperative energy of neighborhood government and town government is additionally settled in each action, one model is the advancement of the travel industry towns by the nearby government and different advancements. This isn't as per the impression of town authorities in the Menganti sub-region, that regardless of whether there is support from the neighborhood government or not, it won't influence the town's local pay.

\section{Impact of Asset Management Professionalism on Increasing Village Original Income}

The third theory is acknowledged, this implies that resource the board demonstrable skill affects expanding town unique pay. As per Sedarmayanti (2013) in (Dewi et al., 2017) polished methodology is a column that will put the administration as a successful machine for the public authority and as a boundary of the contraption's abilities in functioning admirably. The proportion of demonstrable skill is capability, productivity and adequacy just as obligation. Markers of demonstrable skill in overseeing town resources are the way toward arranging, organization, planning, responsibility, announcing and checking of town resources. Town authorities see that if resource the board has been done by existing standards, it will influence the town's unique pay. The impact can be seen from the aftereffects of the relapse coefficients acquired on the variable of polished skill of town resource the executives are positive, this implies that if the town contraption can do resource the board exercises ideally it will build the town's unique pay. This is appeared from the expansion in town unique pay in Menganti subregion which encountered an increment in pay until 2020 (table 1).

\section{CONCLUSIONS AND SUGGESTION}

Improvement of Asset Utilization affects expanding town unique pay, this shows that the use of town resources possessed by towns in Menganti sub-locale can influence the expansion in town unique pay. Streamlining of the utilization of town resources should be possible by using resources claimed by the town by leasing resources having a place with the town to different gatherings, for example, land or rice fields, structures. Town authorities have the insight that in the event that they use the resources possessed by the town ideally, it will expand the town's unique pay. Nearby government support has no impact on expanding town unique pay in Menganti sub-area. Town authorities in Menganti sub-region have the insight that the presence or nonattendance of nearby government backing won't influence the town's unique pay. This can happen in light of the fact that town authorities have mindfulness by improving resource usage and overseeing resources in an expert way can expand town unique pay. Neighborhood government backing should be possible by encouraging and checking town possessed resources. Resource the board polished methodology affects expanding town unique pay. Town authorities see that if resource the executives has been completed by existing principles, it will influence the town's unique pay.

This examination just uses three factors that influence the expansion in town unique pay and is just completed in towns situated in the sub-region of Menganti Gresik Regency. Further examination can add different factors that influence the increment in town unique pay and can be done in different towns that have qualities contrasted with towns in Menganti sub-region.

\section{REFERENCES}

Astuti, Indri. 2015. Pengelolaan Pendapatan Asli Desa (Studi Kasus di Desa Ngombakan Kecamatan Polokarto Kabupaten Sukoharjo Tahun 2014). Skripsi. Universitas Muhamadiyah Surakarta. 
ASSET UTILIZATION OPTIMIZATION, LOCAL GOVERNMENT SUPPORT, ASSET MANAGEMENT PROFESSIONALISM TOWARDS INCREASING VILLAGE ORIGINAL INCOME

Erna Hendrawati

Atmadja, A.T., K.A.K. Saputra dan I.G.M. Tama. 2017. Implementasi Budaya Tri Hita Karana Untuk Mencegah Fraud Dalam Pengelolaan Dana Desa. Prosiding Airlangga National Conference of Accounting (ANCA I 2017).

Atmadja, A,T., dan Saputra, K.A.K. 2018. Determinant Factors Influencing the Accountability of Village Financial Management. Academy of Strategic Management Journal. Vol. 17 No.1. Pp $37-54$.

Dewi, P. E. D. M., Saputra, K. A. K., dan Prayudi, M. A. 2018. Optimalisasi Pemanfaatan dan Profesionalisme Pengelolaan Aset Desa dalam Meningkatkan Pendapatan Asli Desa. Jurnal Ilmiah Akuntansi. Vol.2. No. 2. Pp. 305-32.

Dewi, Istina F. dan Setiawanta, Yulita. 2014. Pengaruh Persepsi Dan Motivasi Mahasiswa Jurusan Akuntansi Yang Sedang Mengambil Skripsi Terhadap Peminatan Karir Dalam Bidang Perpajakan (Studi Empiris Pada Mahasiwa Akuntansi Universitas Dian Nuswantoro). Fakultas Ekonomi dan Bisnis: Universitas Dian Nuswantoro Semarang.

Dewi, P. E. D. M., Prayudi, M. A., \& Saputra, K. A. K. (2017). Hubungan kualitas pengelolaan aset desa dan pendapatan asli desa ( Studi pada Desa-desa di Kabupaten Buleleng - Bali ). In Seminar Nasional Riset Inovatif, 5(3), 253-260.

Ibnu, K., Sukomo, S., \& Dendy, S. A. (2019). Pengaruh Optimalisasi Pemanfaatan Aset Desa Terhadap Pendapatan Asli Desa. 1(1), 112-126.

Natalia, Y. S., NLG Sulindawati, E., \& Atmadja, A. T. (2017). Pengaruh Profesionalisme Pengelolaan Aset Desa, Optimalisasi Pemanfaatan Aset Desa, Dan Pemberdayaan Masyarakat Terhadap Pendapatan Asli Desa (Studi Pada Desa Di Kabupaten Tabanan). EJournal S1 Ak Universitas Pendidikan Ganesha, 7(1), 4.

Permendagri No.113 Tahun 2014

Riyanto, Andi. 2014. Pengaruh Profesionalisme Birokrasi Dan Motivasi Terhadap Kinerja Aparatur Pemerintah Pada Dinas Pendapatan, Pengelolaan Keuangan Dan Aset Daerah Kota Sukabumi. Seminar Nasional Inovasi dan Tren (SNIT) 2014.

Saputra, K. A. K., Jayawarsa, A. A. K., \& Anggiriawan, P. B. (2019). Asset Dan Profesional I Sme Untuk Meningkatkan Pendapatan Asli Daerah ( Pad ). Jurnal Riset Akuntansi Dan Bisnis Airlangga, 4(1), 607-622.

Saputra, K.A.K dan I.P. Julianto. 2016. Pembentukan Bumdesa Dan Komunitas Wirausaha Untuk Meningkatkan Pembangunan Ekonomi di Desa. Prosiding Seminar TEAM Universitas Pendidikan Ganesha.

Saputra, K. A. K., Sujana, E., dan Tama, G. M. 2018. Perspektif Budaya Lokal Tri Hita Karana dalam Pencegahan Kecurangan pada Pengelolaan Dana Desa. Jurnal Akuntansi Publik. Vol.1 No. 1. Pp.28-41.

Sedarmayanti. 2013. Manajemen Sumber Daya Manusia: Reformasi Birokrasi dan Manajemen Pegawai Negeri Sipil. Bandung: Refika Aditama.

Siregar, Doli. D.2004. Management Aset Strategi Penataan Konsep Pembangunan Berkelanjutan secara Nasional dalam Konteks Kepala Daerah sebagai CEO's pada Era Globalisasi dan Otonomi Daerah. Jakarta : PT Gramedia Pustaka Utama.

Undang-undang Republik Indonesia No. 6 Tahun 2014 tentang Desa.

Widayanti, Endang. 2010. Pengaruh Manajemen Aset Terhadap Optimalisasasi Pemanfataan Aset Tetap Pemerintah Daerah (Studi Kasus di Kabupaten Sragen). Tesis, Universitas Sebelas Maret Surakarta.

Yabbar, Rahmah dan Ardi Hamzah, 2015. Tata Kelola Pemerintahan desa: Dari Peraturan Di Desa Hingga Pengelolaan Badan Usaha Milik Desa; Dari Perencanaan Pembangunan Desa Hingga Pengelolaan Keuangan Desa. Surabaya: Pustaka. 